\title{
The impact of institutional quality and governance on financial inclusion in Africa: A two-step system generalised method of moments approach
}

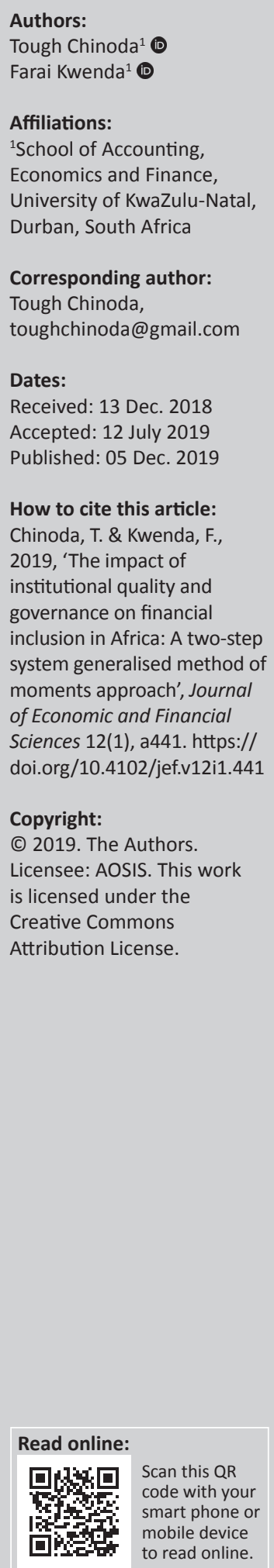

Orientation: Literature emphasises that institutional quality and governance are important elements in enhancing financial inclusion. Studies on institutions, governance and financial inclusion in developing economies found that governance and institutions have positively influenced people wanting to make savings and open a formal bank account.

Research purpose: This study investigated the impact of institutional quality and governance on financial inclusion in Africa.

Motivation of the study: The significance of how governance and institutions affect access to finance has largely been overlooked in previous research. Thus the principal objective of this study is to address this research gap.

Research approach/design and method: A system generalised method of moments technique for a panel data of 49 countries for the period 2004-2016 was employed.

Main findings: The results obtained suggest a positive impact of institutional quality and governance on financial inclusion within the region. Our study also found a significant positive effect of the lagged value of financial inclusion and banking sector size on financial inclusion for African countries. However, rural to total population and natural resources negatively influenced financial inclusion in Africa.

Practical/managerial implications: This study provides implications for policymakers which are fruitful if implemented. Policymakers should facilitate the existence of a transparent legal framework, removal of corruption and enhancing fair administration and judicial proceedings so as to enhance the prospects of financial inclusion. In addition, improving economic freedom and governance levels minifies the informality levels in the financial markets.

Contribution/value-add: This study adds value and knowledge to the current body on financial inclusion and governance issues in Africa, which has not received much attention in developing economies.

Keywords: financial inclusion; governance; institutional quality; System-GMM; co-integration.

\section{Introduction}

The literature emphasises that governance and the quality of institutions are key elements in enhancing financial inclusion. For example, a study by Zulkhibri and Ghazal (2016) on institutions, governance and financial inclusion in developing economies found that governance and institutions have positively influenced people wanting to make savings and/or opening a formal bank account. A recent United Nations Economic for Africa (2016:4) report that focused on the essence of implementing good governance principles highlights how 'institutions and effective economic governance are essential for inclusive development in Africa'. Effective checks and balances, strong enforcement mechanisms and adequate regulatory/legal frameworks are critical drivers of financial inclusion. However, these assumptions have been largely reconsidered in the last two decades with authors such as Barry and Tacneng (2014), arguing that for financial inclusion to succeed, it is vital for reforms to be implemented in the right sequence and at the right speed. From the foregoing discussion, it is probable that financial inclusion has links with institutional quality and governance. Investigating the role of institutions and governance in Africa is therefore fundamental as sustainable financial inclusion aiming at promoting economic growth requires their efficient and robust presence.

We investigated how financial inclusion reacts to changes in institutional quality and governance in Africa. Many factors hinder financial inclusion around the globe. The main barriers can be 
broadly classified as follows: (1) institutional weakness; (2) obstacles developing from banking activities; (3) social, macroeconomic and infrastructure features and (4) regulatory impairment (Zins \& Weill 2016). The literature has also pointed structural and policy-related factors as the two leading driving forces behind financial inclusion across countries (Didier, Love \& Martínez Pería 2012). Lack of deeper understanding on these factors results in poor policy designs. Hence, we contributed to the literature by analysing how governance and institutions affect financial inclusion, using panel data from 49 African countries and the generalised method of moments (GMM) that accounts for endogeneity issues. This article is structured as follows: Section 'Review of financial inclusion, governance and economic freedom' contains the literature on financial inclusion, institutions and governance in Africa; Section 'Methodology and model specification' constitutes the methodology used in the study; Section 'Empirical results' entails the discussions on the empirical findings and results and, finally, Section 'Conclusion' contains the conclusion of the study.

\section{Review of financial inclusion, governance and economic freedom}

The advocates of institutional economics posit that the discourse of institutions is a solemn economics issue and has proved more vital in recent times (Acemoglu et al. 2003; Prasad 2003). Broadly, the performance of institutions commonly relates to measures of corruption, risk of government expropriation, bureaucratic quality, rule of law, openness to trade, repudiation of contracts by government and civil liberties. Although a consensus has been reached that institutional differences and institutions matter are cardinal in explaining the paths of national development, the process of integrating institutional change and institutions into economic theory remains fairly new (Thornton, Ocasio \& Lounsbury 2012). There appears only a basic understanding of the extent to which institutions matter in developing countries. Besides, the channels of influence and causality of the various links between the institutional setup and development outcome remain misunderstood (RodríguezPose 2013). Governance is composed of institutions and traditions by which authority in a country is exercised. This includes the accountability, rule of law and transparency in the selection, monitoring and replacement of governments.

Ali et al. (2019) examined the interplay between the quality of institutions and financial inclusion across 52 developing countries for 2004-2010 using the panel GMM technique. The study found that for developing countries institutional quality promotes financial inclusion. Furthermore, their result shows that financial openness and economic growth positively and significantly influence financial inclusion for the countries under investigation. The study concluded that absence of violence, effective government, political stability and regulatory quality could be a good instrument that may promote financial inclusion. Zulkhibri (2016) used the probit regression to investigate the impacts of institutions and governance on financial inclusion for developing economies.
The results indicate a positive effect of governance on financial inclusion by increasing the number of bank accounts in formal financial institutions and an adverse effect on borrowing behaviour.

Anthony-Orji et al. (2019) investigated the interplay among financial inclusion, financial stability and institutional quality in Nigeria using the unrestricted error correction model of the autoregressive distributed lag. Using quarterly data from 1986 to 2013, the results show a short- and long-run significant positive effect of institutional quality on financial inclusion. The study recommended policymakers following the agenda of financial inclusion pay attention to existing institutional factors. When political, economic, judicial and legal institutions are weak, households and firms may not be protected when there are financial contract enforcement issues or breaches within the economy. This article addresses the crucial question of the impact of institutions and governance on financial inclusion. Although a consensus has emerged that governance and institutions 'matter', the causality links and the influencing channels between the governance, institutional setup and financial inclusion outcomes are still not well understood. An assessment of the impact of governance and institutions is nonetheless needful if policymakers are to evaluate alternative governance and institutional arrangements against those in existence. Our study thus investigated the impact of governance and institutions on financial inclusion outcomes using the GMM model and current data.

\section{Conceptual framework}

The conceptual framework shown in Figure 1 entails the trajectory and dimensions of financial and economic inclusions. It also shows theoretical links on how economic freedom and governance affect financial inclusion. The framework shows that economic freedom and governance contribute to financial inclusion through economic inclusion as a result of increased economic activities that lead to increased availability, accessibility and usage of formal

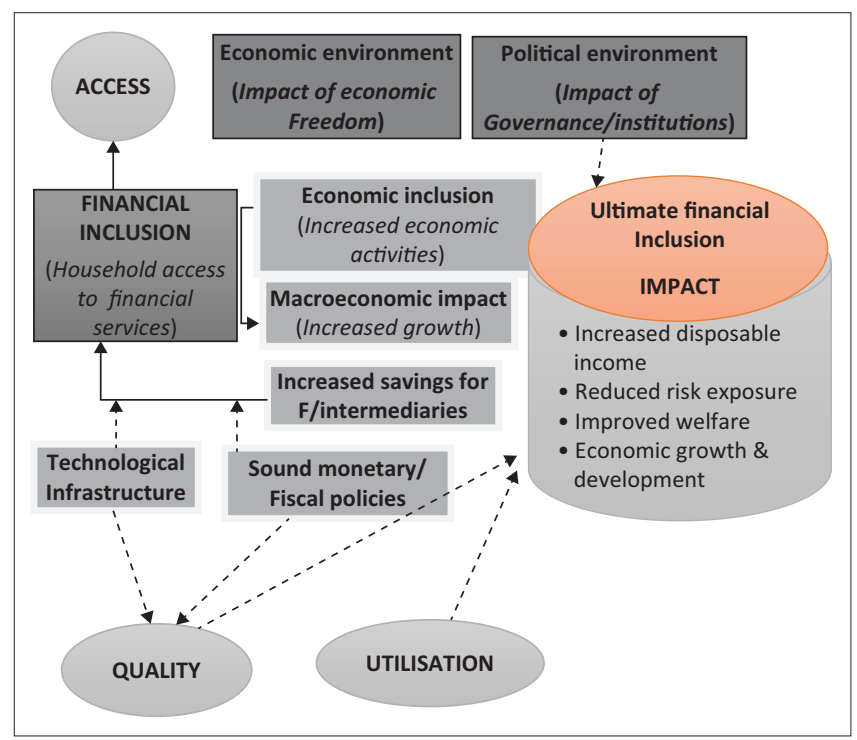

FIGURE 1: Trajectory and dimensions of economic and financial inclusions involving institutional quality (economic freedom) and governance. 
financial services. This shows that inclusion does not occur in isolation. The role played by sound monetary or financial policies, economic freedom and governance quality cannot be downplayed. Institutions and strong economic governance are essential elements in boosting financial inclusion particularly for the vulnerable poor segment of the society because their absence stops transactions, markets and economic activity from functioning well. Governance thus positively influences financial inclusion as it leads to an increase in the saving in the formal accounts and the number of bank accounts although it impacts negatively on borrowing behaviour. Increasing crystal clear legal frameworks, removing corruption, good administration and fair judicial proceedings are key for development and raising prospects of financial inclusiveness. Academics and policymakers (Friedline 2017; Lenka \& Barik 2018) have perceived technological infrastructures such as mobile phones and the Internet as a solution that can outfox poor banking infrastructure and geographical isolation using the network of mobile phones. The high penetration rates and growth of Internet-enabled mobile phones that are changing cell phones into pocket-banks are providing prospects for African countries to proliferate cost-effective and affordable ways of retaining a large number of the adult population that previously has been financially excluded for decades. The increased embracing of mobile phones that are the linked to the Internet has triggered optimism and speculation regarding the possible effects they have on financial inclusion.

\section{Methodology and model specification \\ Methodology}

The existing literature has made use of varied methodologies to investigate the interplay between financial inclusion, institutional governance and economic freedom in Africa. Notable among these methods are probit regression (Zulkhibri, 2016), autoregressive distribution lag (Oleka \& Onyia 2017), ordinary least squares and quantile regression (Agyekum et al. 2016) and correlation analysis (Ndlovu 2018). These methods have their demerits and merits; however, this study employed the robust System-GMM because of its capability to deal with issues of endogeneity that is inbuilt in the regression of variables (financial inclusion, institutional governance and economic freedom) and other control variables. Our study is thus different from Zulkhibri (2016) who investigated the implication of economic freedom and institutional governance on financial inclusion in Africa with probit regression that omits endogeneity issues.

Based on the reviewed literature, we use the financial inclusion index (FII) for financial inclusion, economic freedom and governance index for economic freedom and institutional governance, respectively. Financial inclusion index is best at measuring financial inclusion as it includes all the dimensions of financial inclusion, making it a better choice for the study as it also has strong theoretical basis. Economic freedom and institutional governance index have wide utilisation in the literature, and they measure the overall economic freedom and institutional governance in Africa. Thus, we made use of time-series data (cross-sectional) of the sampled African countries under consideration using GMM. The advantages of the technique inform the choice of panel data analysis. Panel analysis suits the analysis and creation of more difficult behavioural models (Baltagi 2008). The technique also accommodates additional degrees of freedom and is efficient when compared to cross-sectional data and time-series data. Panel analysis is linked with little collinearity and controlled heterogeneity found within individual data (Baltagi 2008). Roodman (2006) states that the GMMdifference estimator, created by Arellano and Bond (1991), works well when the data feature a large number of countries $(N)$ relative to the time period $(T)$ which is the case in this study, where $T=13$ (2004-2016) and $N=49$. The GMM has, however, been contested for ignoring the stationarity of variables as it only captures the short-run time-series dynamics. Thus, it is unclear whether the estimated panel models represent a spurious relationship or a structural longrun equilibrium relationship (Christopoulos \& Tsionas 2004). The other bias of the GMM emanates from the imposition of homogeneous assumption of the lagged dependent variables slope coefficient (Akande \& Kwenda 2017). All these flaws jeopardise the consistence and reliability of the GMM results.

Nevertheless, we applied the Arellano and Bover (1995) orthogonal deviation that Roodman (2006) contends to be more applicable for unbalanced panels with pockets of missing data. Generalised method of moments is a dynamic instrumental variable modelling approach whereby the lags of the dependent variable (financial inclusion) and the differences of explanatory variables (governance, economic freedom, rural to total population and bank size) are used together as instruments to control for any bias (simultaneity bias, endogeneity bias and missing variable bias) introduced, hence avoiding inconsistency of the standard estimator's results. The GMM approach by Arellano and Bover (1995) and Blundell and Bond (1998) is computed from two equations, the original equation and the 'System Generalized Method of Moments' which is a transformed equation. Arellano and Bond (1991) derived both the one- and two-step GMM estimators using moment conditions where the instruments for the differenced equation are lagged levels of both predetermined and dependent variables. To be consistent, we used the Hansen $J$ statistic to validate the instruments of the GMM regressors. Also, the Arellano-Bond test for serial correlation test was used to validate the GMM results. To estimate the relationship between financial inclusion, economic freedom and governance of the African region, we therefore employed the following estimation equation:

$$
\begin{aligned}
& \sum_{j=1}^{p} \gamma_{i} \text { FII }_{t-j}+\beta_{1} \text { GOVERN }_{i, t}+\beta_{2} \text { FREEDOM }_{i, t} \\
& F I I_{t}=\quad+\beta_{3} \text { SIZE }_{i, t}+\beta_{4} \text { RURALTTP }_{i, t}+\psi_{i}+v_{i, t} \\
& + \text { NATURAL }_{i, t} \ldots \ldots \text {... }
\end{aligned}
$$

[Eqn 1]

where $i=1 \ldots N, j=1 \ldots q$ and $t=1 \ldots \ldots T_{i}$

FII represents financial inclusion index; GOVERN represents the institutional governance index; FREEDOM represents 
economic freedom index; SIZE represents bank size proxied by bank deposits as a percentage of gross domestic product; RURALTTP represents rural to total population, $\psi$ : represents the panel-level effects (fixed effects which may be correlated with covariates GOVERN, FREEDOM, SIZE and RURALTTP) and $v_{i, t}$ :is the idiosyncratic error term.

\section{Data and description of variables}

\section{Data and sources}

We used five variables, namely financial inclusion, proxied by FII (the FII which was computed through principal component analysis [PCA]); institutional governance indicators which were computed using the PCA(GOVERN); the economic freedom index (FREEDOM) which was estimated using PCA; bank size proxied by bank deposits as a percentage of GDP (SIZE) and rural to total population (RURALTTPOP). These variables are annual panel data from World Development Indicators (WDI) and International Telecommunication Union (ITU) and span the period 2004-2016.

Table 1 presents the empirical correlations matrix between the indicators of institutional governance. There exists a very strong correlation between corruption and rule of law, regulation and government effectiveness of $0.896,0.88$ and 0.91, respectively, indicating a near-perfect multi-collinearity scenario. While the indicators are strongly correlated with each other, there exists multi-collinearity, which can cause certain misleading inferences. However, this issue is overcome by using PCA and measuring a comprehensive index.

To measure the adequacy of the sample size, we also performed the Kaiser-Meyer-Olkin measure of sampling adequacy (MSA) and the Bartlett test of sphericity as the next requirements. A 0.9 and above MSA value is considered sufficient, meritorious if it is 0.8 and above, middling if it is 0.70 and above, mediocre if it is 0.60 and above, miserable if it is 0.50 and above, and unacceptable if the value falls below 0.50 (Hair et al. 2006). Tables 2 and 3 show that the overall MSA for financial inclusion and institutional governance variables included is meritorious, that is, 0.8551 and 0.8992 , respectively. The probability value of the Bartlett's test of sphericity must be less than the level of significance $(p<0.001)$, which meets the requirement for both indices.

We then used the PCA method to determine the index of institutional governance. As shown in Table 4, data for the

TABLE 1: Correlation matrices for institutional governance.

\begin{tabular}{lcccccc}
\hline Variable & $\mathbf{1}$ & $\mathbf{2}$ & $\mathbf{3}$ & $\mathbf{4}$ & $\mathbf{5}$ & $\mathbf{6}$ \\
\hline Corruption & 1.000 & - & - & - & - & - \\
Government effect & 0.8578 & 1.000 & - & - & - & - \\
PSAV & 0.6695 & 0.6104 & 1.000 & - & - & - \\
Regulation & 0.7855 & 0.8738 & 0.5957 & 1.000 & - & - \\
RO & 0.8960 & 0.9113 & 0.7115 & 0.8788 & 1.000 & - \\
VOA & 0.7266 & 0.6652 & 0.5795 & 0.6862 & 0.7520 & 1.000 \\
\hline
\end{tabular}

Source: Adapted from World Bank, 2018, World development report, World Bank, Washington, DC.

PSAV, political stability and absence of violence/terrorism measures perceptions of the likelihood of political instability and/or politically-motivated violence, including terrorism $\mathrm{RO}$, rule of law; VOA, voice of accountability. institutional governance index suggest that the first component explains about $79.32 \%$ of the variation across the indicators with an eigenvalue of 4.75945 (the only one above 1). Therefore, the first principal component is a more appropriate measure of institutional governance, as it explains better the variations of the interdependent variable than any other linear combination of explanatory variables. Hence, the first principal component information is considered to form a composite indicator as justified by the screen plot diagram in Figure 2. The squared factor loadings

TABLE 2: Extraction method: Principal component analysis.

\begin{tabular}{lccc}
\hline Principal component & Variance (\%) & Cumulative (\%) & Eigenvalues \\
\hline 1 & 0.7932 & 0.7932 & 4.75945 \\
2 & 0.0809 & 0.8741 & 0.485314 \\
3 & 0.0645 & 0.9387 & 0.387239 \\
4 & 0.0339 & 0.9726 & 0.203389 \\
5 & 0.0164 & 0.9890 & 0.0984133 \\
6 & 0.0110 & 1.0000 & 0.0661912 \\
\hline
\end{tabular}

TABLE 3: Components score coefficient matrix.

\begin{tabular}{lc}
\hline Variables & Component 1 \\
\hline Corruption & 0.4258 \\
Government effectiveness & 0.4257 \\
Political stability & 0.3531 \\
Regulation quality & 0.4165 \\
Rule of law & 0.4442 \\
\hline
\end{tabular}

TABLE 4: Summary statistics.

\begin{tabular}{lcccccc}
\hline Year & FREEDOM & GOVERN & NATURAL & FII & SIZE & RURALTTP \\
\hline 2004 & 0.43 & 0.46 & 12.04 & 0.13 & 37.50 & 60 \\
2005 & 0.21 & 0.46 & 13.45 & 0.14 & 38.20 & 60 \\
2006 & 0.19 & 0.47 & 13.84 & 0.10 & 38.28 & 59 \\
2007 & 0.33 & 0.47 & 15.11 & 0.14 & 38.30 & 59 \\
2008 & 0.31 & 0.48 & 16.47 & 0.15 & 38.45 & 58 \\
2009 & 0.06 & 0.47 & 12.50 & 0.16 & 38.50 & 58 \\
2010 & 0.00 & 0.47 & 13.23 & 0.16 & 38.70 & 57 \\
2011 & 0.25 & 0.47 & 15.17 & 0.16 & 38.72 & 57 \\
2012 & 0.26 & 0.47 & 14.53 & 0.16 & 38.75 & 57 \\
2013 & 0.38 & 0.47 & 13.67 & 0.16 & 38.91 & 56 \\
2014 & 0.73 & 0.47 & 12.04 & 0.17 & 39.00 & 56 \\
2015 & 0.82 & 0.47 & 10.41 & 0.17 & 39.28 & 55 \\
2016 & 1.00 & 0.47 & 11.51 & 0.17 & 39.50 & 55 \\
\hline Overall & $\mathbf{0 . 3 8}$ & $\mathbf{0 . 4 7}$ & $\mathbf{1 3 . 3 8}$ & $\mathbf{0 . 1 5}$ & $\mathbf{3 8 . 7 0}$ & $\mathbf{5 7}$ \\
\hline
\end{tabular}

FIl, financial inclusion index.

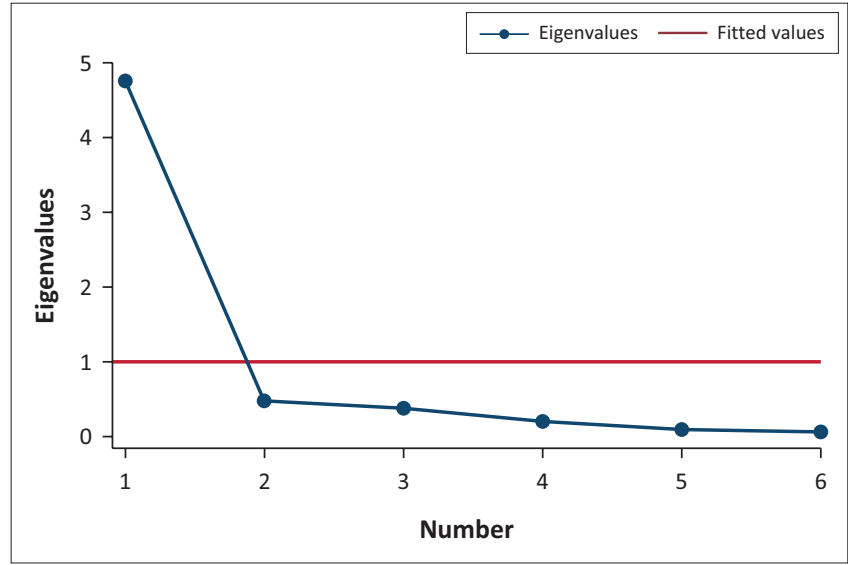

FIGURE 2: Screen plot of the components (of eigenvalues after principal component analysis). 
from the PCA are used to ensure that the weights add up to 1. The squared factor loadings show the degree of variation explained by each factor, such that more weight is assigned to an indicator with a higher contribution on the common variation. Thus, a composite institutional governance indicator (IG index-1) is obtained.

The economic freedom index measures the level of economic freedom, utilising 10 broad categories, namely freedom on business, corruption, fiscal, trade, government spending, financial, monetary, investment, property rights and labour, on a scale from 0 to 100 , with 100 representing higher degrees of freedom. Economic freedom empowers people with opportunities to decide for themselves how to trail and realise their dreams, subject to honest competition and the basic rule of law. Governments that promote and respect economic freedom offer the best atmosphere for innovation, experimentation and progress, which enables humankind to grow in prosperity and well-being. The study used annual economic freedom index sourced from the database of The Heritage Foundation. We expect the relationship between economic freedom and financial inclusion to be positive.

\section{Ethical considerations}

All ethical issues have been adhered to; work has been acknowledged and referenced. Ethical clearance and approval letter of research provided.

\section{Empirical results}

The summary statistics provides an appreciation of the data used in this study. Table 4 presents the summary statistics which deliver an understanding into the data used in the study. The mean values of the listed variables indicate that Africa is a less resilient continent. The economic freedom (FREEDOM) and institutional governance (GOVERN) support this assertion as their mean over the period is weak and falls below the global benchmark of 0.5 . The data suggest the presence of poor governance structures in Africa, based on the aggregate normalised institutional governance index. The average index for the sample of countries in Africa is 0.47, which corroborates a long-standing finding by Zulkhibri and Ghazal (2017) that governance crisis is the main factor underlying the petitions of Africa's development problems. Bräutigam and Knack (2004) suggest a multiplicity of reasons for poor governance in Africa, including corruption, underdeveloped legal systems and poor institutional framework, among others. The Fraser Institute methodology shows that lower ratings of the indices show a heavy-handed government intervention in markets, while higher ratings correspond to more economic freedom. The governance indicators database also shows that higher ratings of governance correspond to good governance and vice versa. Because the overall mean index of economic freedom and governance falls below the benchmark of 0.5 , it shows that African economies are characterised by poor governance and heavy-handed government interventions that are likely to affect access to finance. This could be because of over-reliance on government budgets and political decision-making. Gwartney \& Halcombe (2016) opine that the GOVERN index tends to be high in countries where rent-seeking is not an issue, that is, when countries depend more on government budgets and political decision-making than personal choice. The 2016 edition of the global Economic Freedom report, copublished by the Fraser Institute and the Cato Institute, found that globally Africa ranked at the bottom with regard to economic freedom (Gwartney \& Halcombe 2016). Also, the 2016 report by the World Bank on Ease of Doing Business reckoned Africa as the most difficult region for starting a business in the world because of poor governance and violated economic freedom (Gwartney \& Halcombe 2016). Policymakers should therefore craft policies that promote sound institutional governance and strong institutional and legal frameworks. Based on Table 4, 10.41\%-16.47\% for the sampled countries in the region are dependent on natural resources rents share of GDP. The mean banking sector size in Africa is $38.7 \%$, which shows that banking sector size is large enough to influence access to finance. The results show that size of the bank is positively associated with financial inclusion activities. This is not surprising, as larger firms are more visible and attract greater public and government scrutiny.

Rural concentration, which is the ratio of rural population to total population, indicates that the African region has the highest percentage of its population residing in rural areas at $57 \%$, further complicating the poverty structure. This factor potentially has a significant negative impact on household income and the call for financial services. ${ }^{1}$ Such unique features within Africa make the region ideal for examining the dynamic interplay between the dual effect of economic and financial underperformance on financial inclusion.

The study proceeded to analyse the correlation between the exogenous and endogenous variables of interest in Table 5. Correlation analysis indicates the likelihood of multicollinearity and endogeneity problems associated with a number of econometric models. Table 5 shows that a significant positive correlation exists between financial inclusion and other variables such as institutional governance, banking sector size (bank deposits to GDP) and economic freedom. Interestingly, the results suggest a negative association between financial inclusion and other variables such as natural resources, population size (market size) and rural concentration. This could be as a result of high underdevelopment in rural areas in Africa. This is in line with Yorulmaz (2016), who finds a negative relationship between financial inclusion and rural population for European Union countries. The negative effect of natural resources could suggest the presence of the natural resource curse (Sachs \& Warner 1999, 2001) in Africa where countries with abundant natural resource are associated with reduced financial inclusion. Overall, the study found a strong association with mixed signs and more significances between the variables.

1.Rural concentration for South Asia and North America was $70.91 \%$ and $19.4 \%$ respectively, while that of East Asian Pacific, Middle East, Europe and Central Asia and Latin America and Caribbean was 50\%, 20\%, 34\% and 39\%, respectively. 
TABLE 5: Results of correlation analysis.

\begin{tabular}{|c|c|c|c|c|c|c|c|}
\hline Variable & $p$-value & FII & GOVERN & NATURAL & SIZE & FREEDOM & RURALLLP \\
\hline FII & - & 1.0000 & - & - & - & - & - \\
\hline \multirow[t]{2}{*}{ GOVERN } & Standard error & $0.5430 *$ & 1.0000 & - & - & - & - \\
\hline & $p$ & 0.0000 & - & - & - & - & - \\
\hline \multirow[t]{2}{*}{ NATURAL } & Standard error & $-0.3212^{*}$ & $-0.4512^{*}$ & 1.0000 & - & - & - \\
\hline & $p$ & 0.0000 & 0.0015 & - & - & - & - \\
\hline SIZE & Standard error & $0.6384 *$ & $0.4460 *$ & $-0.3148^{*}$ & 1.0000 & - & - \\
\hline \multirow[t]{2}{*}{ FREEDOM } & Standard error & $0.2844 *$ & $0.7048^{*}$ & $-0.4584^{*}$ & $0.3221 *$ & 1.0000 & - \\
\hline & $p$ & 0.0000 & 0.0000 & 0.0000 & 0.0000 & - & - \\
\hline \multirow[t]{2}{*}{ RURALTTP } & Standard error & $-0.3538^{*}$ & $-0.1255^{*}$ & $-0.1769 *$ & $-0.4446 *$ & 0.0036 & 1.0000 \\
\hline & $p$ & 0.0000 & 0.0000 & 0.0000 & 0.0000 & 0.9299 & - \\
\hline
\end{tabular}

FII, financial inclusion index.

$*, p<0.05$.

Figures 3 and 4 show the association between financial inclusion, economic freedom and governance (measured by the index of governance), respectively. The data suggest the presence of a non-linear positive relationship between indicators of financial inclusion and economic freedom and also between financial inclusion and governance index in line with Law and Saini (2012). This would suggest that improved governance and economic freedom have a potential of expanding financial inclusion for African countries.

\section{Two-step system generalised method of moments analysis}

The dynamic panel model used the vigorous two-step System-GMM with orthogonal deviation, the results being displayed in Table 6. This has the ability to handle unbalanced panel data analysis and was proven in resolving panel data bias. Table 6 shows that the results meet the diverse requirements of the regression models: especially the Wald test probability for the GMM indicates the goodness of the overall fitness of the result. In addition, the result of the Hansen $J$ statistics and AR2 confirms the absence of overidentification of the instruments and serial correlation. We therefore analysed and further discuss the results. A rather interesting result was obtained from the GMM regression.

Table 7 shows the economic implications of the regressions of significant variables in Table 6. It shows in percentage how 1 standard deviation increase in the dependent variable economically impacts financial inclusion.

\section{Economic implications of regression}

An analysis of the results shows that the lagged financial inclusion values exhibit strong positive significance, indicating that past financial inclusion levels impact positively on current levels of financial inclusion. We found financial inclusion to be strongly significant and positively related to governance (GOVERN) and economic freedom (FREEDOM), implying that improvement in governance and economic freedom increases financial inclusion. In terms of economic implication, a 1 standard deviation increase in governance and economic freedom increases financial inclusion by $34 \%$ and $18 \%$, respectively. This result is consistent with Zulkhibri (2016),

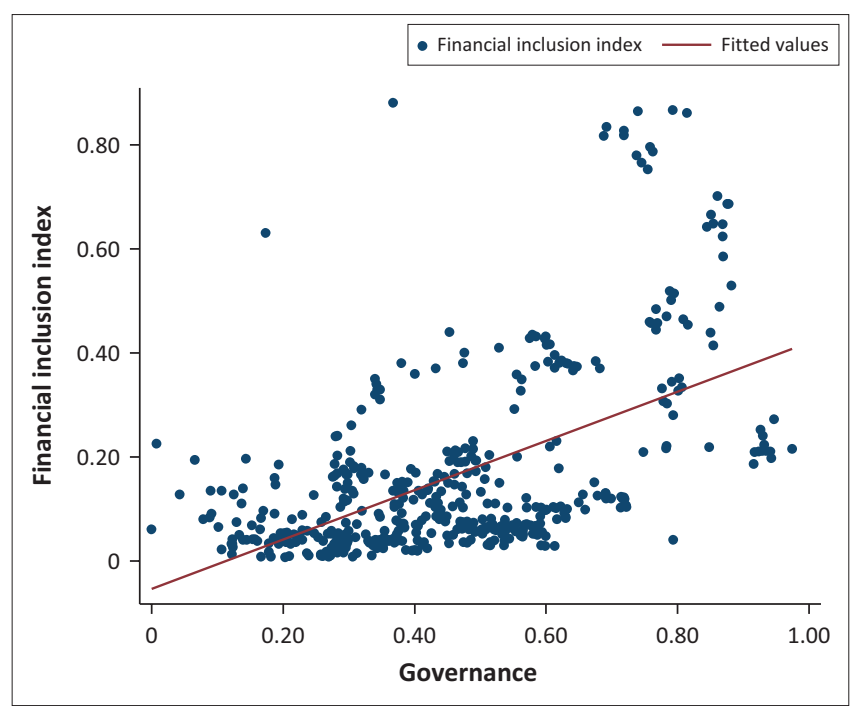

FIGURE 3: Institutional governance.

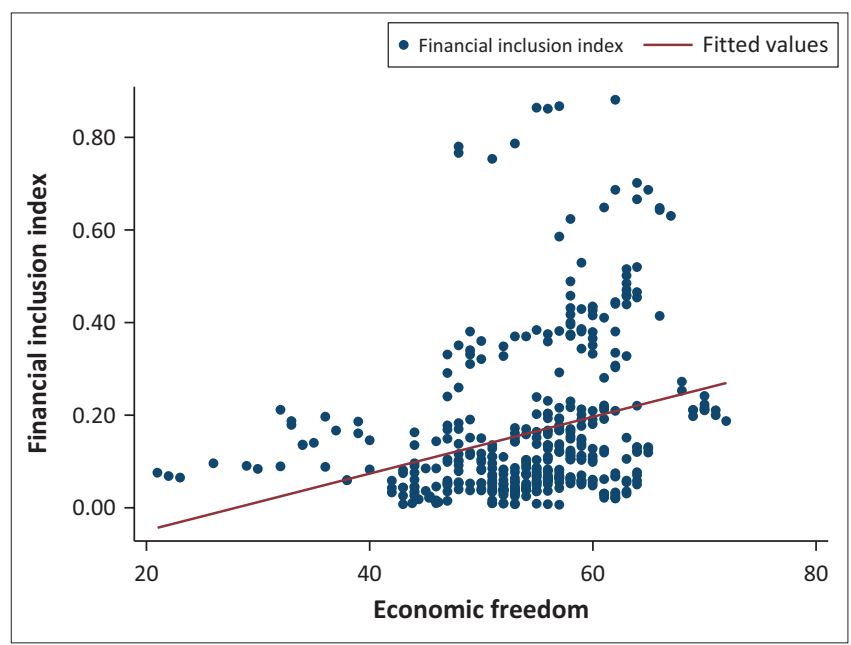

FIGURE 4: Economic freedom.

who found financial inclusion to be positively related to institutional governance in Muslim and developing economies. In fact, the economic implication shows that 1 standard deviation increase in governance and economic freedom will significantly increase financial inclusion by $34 \%$ and $18 \%$, respectively. This confirms existing theories and empirical literature that posit a positive relationship between governance 
TABLE 6: The results from two-step generalised method of moments approach.

\begin{tabular}{|c|c|c|}
\hline \multirow{2}{*}{$\begin{array}{l}\text { Dependent variable: FII } \\
\text { Independent variables }\end{array}$} & \multicolumn{2}{|c|}{ GMM model (FII) } \\
\hline & Coefficient & Probability \\
\hline Lagged financial inclusion index & $0.4708 * * *$ & 0.000 \\
\hline Economic freedom & $0.0042 * * *$ & 0.000 \\
\hline Governance index & $0.297 * * *$ & 0.000 \\
\hline Bank size & $0.0024 * * *$ & 0.000 \\
\hline Natural resources & $-0.0024 * * *$ & 0.000 \\
\hline Rural concentration & $-0.0048 * * *$ & 0.000 \\
\hline Constant & $1.028 * * *$ & 0.000 \\
\hline Observations & - & 407 \\
\hline$R^{2}$ & - & - \\
\hline Wald $c h i^{2} \chi^{2}(6)$ & - & 761.73 \\
\hline Prob $>F / c h i^{2}$ & - & 0.000 \\
\hline$A R(2)$ probability & - & 0.36 \\
\hline Hansen $J$ statistic & - & 0.516 \\
\hline
\end{tabular}

AR, autoregressive; FII, financial inclusion index; GMM, generalised method of moments; Prob, probability.

$* * *, p<0.05$.

TABLE 7: Economic impacts of regression results.

\begin{tabular}{ll}
\hline Dependent variable: FII & FII \\
\hline Economic freedom & 0.1799 \\
Governance & 0.3428 \\
Rural concentration & -0.4699 \\
Natural resources & -0.1768 \\
Bank size & 0.3350 \\
\hline
\end{tabular}
Note: Economic Impact $=\frac{S D \text { of independent variable } * R . C \text { of independent variable }}{S D \text { of dependent variable }}$, where

$\mathrm{RC}$ is regression coefficient and SD is standard deviation.

$\mathrm{FII}$, financial inclusion index.

and financial inclusion and also between economic freedom and financial inclusion.

We, however, found financial inclusion to be inversely related to rural concentration (RURALTTP) and natural resources (NATURAL). The implication is that natural resources and rural concentration do not pose any complicity in financial inclusion in the region, as a 1 standard deviation increase in natural resources, rural concentration and market size lowers financial inclusion by $0.24 \%$ and $0.48 \%$, respectively. Also, the size of the banking sector exhibits a positive and strong significance in relation to financial inclusion. Hence, as banking sector size increases so does the financial inclusion. This is also in line with Uddin, Chowdhury and Islam (2017), who found size as a significant determinant of financial inclusion in Bangladesh. The sign is the same for the economic implications as a 1 standard deviation increase in rural concentration and natural resources rents reduces financial inclusion by $0.5 \%$ and $0.17 \%$, respectively. The result on rural concentration is better explained by an understanding of the relationship between financial inclusion and the dependency ratio in line with Allen et al. (2016). This suggests that countries with large population sizes concentrated in rural areas have difficulties in extending access to financial services. Financial service provision in rural centres is not cost-effective because of the dispersion of population in many African countries. The inverse relationship could also be a result of infrastructure-related barriers in rural areas like limited number of ATMs and branches against the population.
To compound the situation, Noor (2017) has stressed that the absence of a convenient transport network to ATMs and bank branches as well as a reliable mobile telephone communication and the absence of the infrastructure itself hinder financial inclusion. It is difficult to achieve financial inclusion if there is no access to reliable and secure settlement and payment systems (Miethe \& Pothier 2016). Policymakers should come up with policies that encourage the construction of road networks, infrastructure and improvements on network availability. The availability of infrastructure makes it cheaper for financial institutions to provide their services (Zins \& Weill 2016). This may, in turn, have a positive impact on business activities because customers are more likely to face reduced transaction costs, thus increasing the overall demand for financial services.

Overall, the result is in agreement with the regression models requirements, as displayed in Table 6. The overall fitness of the GMM result is good as pointed by the Wald test probability, and the result of the Hansen $J$ statistics shows that the instruments are not over-identified and $\mathrm{AR}(2)$ confirms that there is no serial correlation.

\section{Discussion of findings}

The significant positive and tenacious relationship between the lagged and current value of financial inclusion suggests that a financially inclusive economy in the past period has a propensity to replicate the same pattern today and in future and/or even to increase unless some policies are implemented to reverse the trend. This calls for continual efforts in ensuring inclusive financial inclusion at all times for enhanced economic growth in Africa. As in the words of Evans and Osi (2016), financial inclusion is key to economic growth to a point that the modern economic growth is crippled by financial exclusion.

The results of a positive relationship between institutional governance, economic freedom and financial inclusion are in line with Zulkhibri's (2016) view. Political stability and the quality of regulation are good illustrations of how applicable the governance indicators are to financial inclusion. If the political situation of a country is bad, the people will not engage seriously in any financial activities because of lack of trust. This is evidence that an enhanced institutional quality and economic freedom actually contributes substantially to financial inclusion, particularly for the poor segments of the society. The results also suggest that good governance is essential for raising and development of chances of financial inclusiveness. However, many developing countries incur governance challenges. A number of developing countries rank below global averages in terms of rule of law, government effectiveness and political stability (Holmes, Feulner \& O'Grady 2014). Institutional quality (governance) and economic freedom must be given maximum attention if financial inclusion is to bring forth benefits for the region. African countries should strengthen macro-prudential policies and adopt the right form of governance policies that 
do not aggravate financial inclusion. Furthermore, improved level of governance reduces the levels of informality in the financial markets. However, the results are not consistent with Oleka and Onyia (2017), who examined the impact of institutional quality on financial inclusion in Nigeria and concluded that institutional quality has no significant impact on financial inclusion over the period 1988-2015 in the short run, though it is significant in the long run.

We found evidence of a significant positive relationship between bank size and financial inclusion in line with Uddin et al. (2017) and Nawaz (2018). This could be as a result of efficiency and economies of scale enjoyed by large banks. There is need for a reasonable bank size to facilitate the viability of the banking system. However, the size must be managed to avert the negative side of excessive credit supply that could threaten economic growth as a result of bad loans. However, this finding is contrary to Beck (2012), who used data from The World Bank's Enterprise Surveys for 33 emerging and developing countries and established that lower access to financial services results from the dominance of banks in a financial system. Contrary to theoretical expectations, Beck (2012) found no evidence that the size of financial institutions affects access to finance. In addition, Gimet and Lagoarde-Segot (2012) examined the relationship between financial structure and firms' access to financial services for 138 countries over the period 2002-2009. These researchers' findings suggest that there is a need to enhance competition, improve capital market development and institute effective regulatory and supervisory policies instead of focusing on banking sector size, so as to effectively promote access to finance. The policy implication is that access to credit and savings from big banks could lead to monopolies which in future could lead to instabilities, thus affecting growth. Furthermore, policymakers should make policies that strike a balance between small and big banks.

The inverse relationship between financial inclusion and rural concentration found in this study is in line with Ndlovu (2018). Based on the estimations, a high concentration of population in rural areas is related to financial underperformance. Economic insight would suggest that this is an outcome of both demand and supply factors. As a result of poor development of 'state variables' in rural areas, supply is normally reduced as financial institutions find it difficult to operate in such areas. On the contrary, people residing in rural areas generally have less demand for financial services, bringing about low usage. Thus, institutions would concentrate on high-value transaction areas, resulting in reduced access in low-value transaction areas (Beck \& De La Torre 2006). Therefore, it is essential to improve 'state variables' in rural areas to reduce institutions' operation costs. Also, in rural areas, fewer employment opportunities, less availability of bank branches, low income and levels of financial education and other socio-economic factors inhibit local residents from fully participating in banking services. In terms of policy implications, it is vital to come up with financial literacy programmes that equip people with knowledge on credit options and saving. Financial education can raise awareness on different benefits and uses of mobile banking. It also gives a customer an understanding of basic concepts of finance. Policymakers can take advantage of the rise in secondary education to spread awareness on the advantages of financial inclusion. This financial awareness encourages consumers not to invest or borrow in informal financial sectors, thereby protecting themselves from unfair practices.

\section{Conclusion}

We investigated the impact of institutions and governance on financial inclusion in Africa for the period 2004 and 2016. Overall, we found a positive impact of institutional quality and governance on financial inclusion within the region. Hence, individual countries should devise effective ways of ensuring quality institutions and good governance. The results of the study suggest the presence of a positive relationship between the lagged value of financial inclusion, institutional governance, economic freedom, banking sector size and financial inclusion for African countries. However, rural to total population, population (market size) and natural resources negatively influence financial inclusion in Africa. Based on the estimations, a high concentration of population in rural areas is related to financial underperformance. Economic insight would suggest that this is an outcome of both demand and supply factors. As a result of poor development of 'state variables' in rural areas, supply is normally reduced as financial institutions find it difficult to operate in such areas. Alternatively, people residing in rural areas generally have less demand for financial services, bringing about low usage. Thus, institutions would concentrate on high-value transaction areas, resulting in reduced access in low-value transaction areas (Beck \& De La Torre 2006). Therefore, it is essential to improve 'state variables' in rural areas to reduce institutions' operation costs.

Considerable policy relevance is presented by the findings of this study. Bearing in mind that formal finance can be used as a tool to combat poverty and social exclusion and to increase economic growth, increasing transparent legal framework, removing corruption and enhancing fair administration and judicial proceedings are vital for the raising and development of chances of financial inclusiveness. In addition, improving the economic freedom level and governance reduces the informalities in the financial markets. It is essential to attract individuals who are operating in informal markets, irrespective of how poor they are, as they participate in numerous financial activities to build assets, cover daily transactions and prepare for life events and emergencies.

\section{Acknowledgements}

The authors would like to express their appreciation for the financial support in the form of fees remission provided by the University of KwaZulu-Natal, which enabled the undertaking of this study. 


\section{Competing interests}

The authors declare that they have no financial or personal relationships that may have inappropriately influenced them in writing this article.

\section{Authors' contributions}

T.C., the corresponding author, is a $\mathrm{PhD}$ scholar from the University of KwaZulu-Natal, researching the nexus between mobile phones diffusion, financial inclusion and economic growth evidence in Africa. Dr F. Kwenda, the second author, is the supervisor of the $\mathrm{PhD}$ thesis; he has assisted in the supervision of the article.

\section{Funding information}

This study was supported by the University of KwaZuluNatal in terms of fees remission. The authors would not have completed this work without their support.

\section{Data availability statement}

Data sharing is not applicable to this article as no new data were created or analysed in this study.

\section{Disclaimer}

The submitted article is the authors' own work and not an official position of the institution or funder.

\section{References}

Acemoglu, D., Johnson, S., Robinson, J. \& Thaicharoen, Y., 2003, 'Institutional causes, macroeconomic symptoms: Volatility, crises and growth', Journal of Monetary Economics 50(1), 49-123. https://doi.org/10.1016/S0304-3932(02)00208-8

Agyekum, F.K., Locke, S. \& Wellage, N.H., 2016, 'Financial inclusion in Ghana: doesinstitutionalcontextmatter?', Papier présenté au 20ème colloque sur la finance de Nouvelle Zélande, 10-12 février 2016. Université de Otago, Queetown.

Akande, J.O. \& Kwenda, F., 2017, 'P-SVAR analysis of stability in sub-Saharan Africa commercial banks', SPOUDAl-Journal of Economics and Business 67(3), 49-78.

Ali, H.S., Zeqiraj, V., Lin, W.L., Law, S.H., Yusop, Z., Bare, U.A.A. et al., 2019, 'Does quality institutions promote environmental quality?', Environmental Science and Pollution Research 26(11), 10446-10456.

Anthony-Orji, O.I., Orji, A., Ogbuabor, J.E. \& Nwosu, E.O., 2019, 'Do financial stability and institutional quality have impact on financial inclusion in developin economies? A new evidence from Nigeria', International Journal of Sustainable Economy 11(1), 18-40.

Allen, F., Demirguc-Kunt, A., Klapper, L. \& Peria, M.S.M., 2012, The foundations of financial inclusion: Understanding ownership and use of formal accounts, The World Bank, Washington, DC

Arellano, M. \& Bond, S., 1991, 'Some tests of specification for panel data: Monte Carlo evidence and an application to employment equations', The Review of Economic Studies 58(2), 277-297.

Arellano, M. \& Bover, O., 1995, 'Another look at the instrumental variable estimation of error-components models', Journal of Econometrics 68(1), 29-51. https://doi. org/10.1016/0304-4076(94)01642-D

Baltagi, B., 2008, Econometric analysis of panel data, John Wiley \& Sons, Hoboken, NJ.

Barry, T.A. \& Tacneng, R., 2014, 'The impact of governance and institutional quality on MFI outreach and financial performance in Sub-Saharan Africa', World Development $58,1-20$

Beck, T. \& De La Torre, A., 2006, The basic analytics of access to financial services, The World Bank, Washington, DC.

Beck, T., 2012, 'Finance and growth-lessons from the literature and the recent crisis', LSE Growth Commission 3, 01-06.
Blundell, R. \& Bond, S., 1998, 'Initial conditions and moment restrictions in dynamic panel data models', Journal of Econometrics 87(1), 115-143. https://doi. org/10.1016/S0304-4076(98)00009-8

Bräutigam, D.A. \& Knack, S., 2004, 'Foreign aid, institutions, and governance in subSaharan Africa', Economic Development and Cultural Change 52(2), 255-285. https://doi.org/10.1086/380592

Christopoulos, D.K. \& Tsionas, E.G., 2004, 'Financial development and economic growth: Evidence from panel unit root and cointegration tests', Journal of Development Economics 73(1), 55-74. https://doi.org/10.1016/j.jdeveco.2003.03.002

Didier, T., Love, I. \& Martínez Pería, M.S., 2012, 'What explains co-movement in stock market returns during the 2007-2008 crisis?', International Journal of Finance \& Economics 17(2), 182-202. https://doi.org/10.1002/ijfe.442

Evans, O.L.A.N.I.Y.I. \& Alenoghena, O.R., 2017, 'Financial inclusion and GDP per capita in Africa: A Bayesian VAR model', Journal of Economics \& Sustainable Development 8(18), 44-57.

Friedline, 2017, An open internet is essential for financial inclusion, FinTech revolution, HuffPost, viewed 18 April 2018, fromwww.huffingtonpost.com/entry/an-openInternet-is-essential-for-financial-inclusion_us_5a3345dce4b0e1b4472ae520.

Gimet, C. \& Lagoarde-Segot, T., 2012, 'Financial sector development and access to finance. Does size say it all?', Emerging Markets Review 13(3), 316-337. https:// doi.org/10.1016/j.ememar.2011.11.002

Gwartney, J. \& Holcombe, R., 2016, Robert Lawson, and Joshua Hall, 'economic freedom of the world: 2016 annual report', Fraser Institute, Vancouver.

Hair, J.F., Jr., Black, W.C., Babin, B.J., Anderson, R.E. \& Tatham, R.L. (eds.), 2006 , Multivariate Data Analysis, 6th edn., Pearson Prentice Hall, Upper Saddle River, NJ.

Holmes, K.R., Feulner, E.J. \& O'Grady, M.A., 2014, 2014 index of economic freedom, The Heritage Foundation, Washington, DC.

Law, S.H. \& Azman-Saini, W.N.W., 2012, 'Institutional quality, governance, and financial development', Economics of Governance 13(3), 217-236. https://doi. org/10.1007/s10101-012-0112-z

Lenka, S.K. \& Barik, R., 2018, 'Has expansion of mobile phone and internet use spurred financial inclusion in the SAARC countries?', Financial Innovation 4(1), 5. https:// doi.org/10.1186/s40854-018-0089-x

Miethe, J. \& Pothier, D., 2016, 'Brexit: What's at stake for the financial sector?', DIW Economic Bulletin 6(31), 364-372.

Nawaz, T., 2018, 'Lifting the lid on financial inclusion: Evidence from emerging economies', International Journal of Financial Studies 6(2), 59. https://doi. org/10.3390/ijfs6020059

Ndlovu, G., 2018, 'Access to financial services: Towards an understanding of the role and impact of financial exclusion in sub-Saharan Africa', Doctoral dissertation, University of Cape Town.

Noor, H., 2017, 'Determining factors that influence financial inclusion among SMEs: The case of Harare Metropolitan', Doctoral dissertation, University of Cape Town

Oleka, C.D. \& Onyia, C., 2017, Improvement in institutional quality and financial inclusion in Nigeria (1988-2015), ISSN: 2579-0773, 33-45.

Prasad, B.C., 2003, 'Institutional economics and economic development: The theory of property rights, economic development, good governance and the environment', International Journal of Social Economics 30(6), 741-762. https://doi.org/10.1108/ 03068290310474120

Rodríguez-Pose, A., 2013, 'Do institutions matter for regional development?', Regional Studies 47(7), 1034-1047.

Roodman, D., 2006, 'How to do xtabond2: An introduction to difference and system GMM in Stata', Stata Journal: StataCorp LP, 9(1), pages 86-136.

Sachs, J.D. \& Warner, A.M., 1999, 'The big push, natural resource booms and growth'. Journal of Development Economics 59(1), 43-76.

Sachs, J.D. \& Warner, A.M., 2001, 'The curse of natural resources', European Economic Review 45(4-6), 827-838.

Thornton, P.H., Ocasio, W. \& Lounsbury, M., 2012, The institutional logics perspective: A new approach to culture, structure, and process, Oxford University Press on Demand, Oxford.

Uddin, A., Chowdhury, M.A.F. \& Islam, M.N., 2017, 'Determinants of financial inclusion in Bangladesh: Dynamic GMM \& quantile regression approach', The Journal of Developing Areas 51(2), 221-237. https://doi.org/10.1353/jda.2017.0041

UNECA, A.S.B.E., 2016, A policy handbook, UN Economic Commission for Africa (UNECA), Addis Ababa.

World Bank, 2018, World development report, World Bank, Washington, DC.

Yorulmaz, R., 2016, 'Essays on global financial inclusion', Doctoral dissertation, University of Sheffield.

Zins, A. \& Weill, L., 2016, 'The determinants of financial inclusion in Africa', Review of Development Finance 6(1), 46-57. https://doi.org/10.1016/j.rdf.2016.05.001

Zulkhibri, M., 2016, Financial inclusion, governance and institution: Evidence from developing economies, Governance and Institution: Evidence from Developing Economies, January 22, 2016

Zulkhibri, M. \& Ghazal, R., 2017, 'The Impacts of Governance and Institution on Financial Inclusion: Evidence from Muslim Countries and Developing Economies'. Journal of King Abdulaziz University: Islamic Economics 30. 